\title{
IMPACT OF STOCK MARKETS ON THE ECONOMY IN THE V4 COUNTRIES
}

\author{
Radmila Krkošková1
}

Silesian University in Opava, School of Business Administration in Karviná, Department of Informatics and Mathematics, ORCID: 0000-0002-4977-0060,krkoskova@opf.slu.cz.

\begin{abstract}
The performance of the economy should generally reflect the performance of stock markets. Production increases, prices rise, and companies' profits increase if the economy grows. And the shares should naturally make the profits (which means among other things, higher dividends) even more attractive. But is that really true? The aim of the article is to find out the relationship between the development of stock markets and the economic growth in Visegrad Group countries (V4). The subject of the survey is both the long-term relationship and the short-term relationship in the course of economic cycles. The article uses the tools of time series econometrics, especially VECMs, including corresponding diagnostics, Granger causality and block erogeneity. The relationships between the variables examined vary from country to country. The long-term relationship between the development of stock markets and the economic growth was confirmed in Slovakia and Hungary. It was confirmed that the GDP growth rate influenced the growth rate of stock indices in all V4 countries. The opposite relationship (the stock index growth rate influences the GDP growth rate) was not confirmed only in the Czech Republic. Quarterly data for the period from 2005/Q1 to 2018/Q4 was used for the analysis. This period was selected because all of the V4 countries have been members of the European Union since 2004. The EViews software version 9 was used for the calculations. Variables used in this research are: the GDP, the stock exchange index of the country and stock trading volume. The PX, SAX, BUX and WIG20 stock indices are considered to be the crucial representatives of individual stock markets in this work.
\end{abstract}

Keywords: ADF test of stationarity, Granger causality, impulse-response analysis, stock market, VECM, V4.

JEL Classification: C19, C50, D53.

APA Style Citation: Krkošková, R. (2020). Impact of Stock Markets on the Economy in V4 Countries. E\&M Economics and Management, 23(3), 138-154. https://doi.org/10.15240/ tul/001/2020-3-009

\section{Introduction}

The objectives and common interests of the V4 countries were described in the Visegrad Declaration (1991). One of the objectives was to create favorable conditions for direct cooperation between enterprises, for foreign capital investment, for the development of financial and stock markets. And this is the reason why the countries of V4 were selected for the analysis. The paper could confirm the relationship between the development of stock markets and the economic growth in the V4. Following the admission of the V4 countries to the European Union in 2004, Visegrad Four's foreign-policy activities increased significantly and the group focused on promoting cooperation and stability in the wider Central European region. The article dealt with the effects of the stock market on the economy in individual countries and discusses the relationship between the GDP, the stock trading volume and the index rate. The goal of this paper is to find if exists the long-term relationship and the shortterm relationship between variables. Why is the mutual dependence of the GDP and income from shares different in the V4 countries?

The relation between macroeconomic variables and the movement of stock prices 
has been documented well in the literature over the last several decades. It is often argued that stock prices are determined by some fundamental macroeconomic variables. This work is based on the fact that stock quotes respond to events that affect the equity and economic markets before GDP. The long-term relationship between the development of stock markets and the economic growth was not confirmed in all countries.

This article is divided into five parts. The introduction explains why the V4 countries were selected for the analysis. The first chapter contains a review of literature. The second part describes the econometric methods used. The third part describes the economic development and development of individual the V4 markets in the period from 2005 to 2018 . The core of this article is the fourth chapter dealing with modelling for each country which is performed here separately. The results of the work are presented in the conclusion.

\section{Literature Review}

Most authors currently believe that financial markets positively contribute to the economic growth as discussed in the work by, for example, Bekaert and Harvey (1998) of financial markets.

There are different views of Arestis, Demetriades and Luintel (2001) and others. According to them, the economic growth rate can be maintained without the existence of technological development, mainly due to the influence and the importance of financial markets for the economic growth. Bekaert and Harvey (1998) are of the opinion that authors who assert that the existence of stock markets is of little importance for real economic growth, forget the several roles that equity markets hold. One of these roles is the ability to diversify.

Olweny and Kimani (2011), Wanzala, Muturi and Olweny (2017) attach importance to stock markets in combination with the economic growth because they enable corporations and governments to accumulate long-term capital and hence fund new projects.

Arestis, Demetriades and Luintel (2001) show in their empirical analysis that stock markets can contribute to the long-term economic growth, but their impact is only part of the influence of the banking system. The authors examined quarterly time series from 1968 to 1998 in the fully developed economies of the following countries: the USA, the United
Kingdom, France, Germany, and Japan. The results differed for each country.

In their articles, Caporale, Howells and Soliman (2004), Dritsaki and Bargiota (2004) deal with the causal relationship between stock and credit markets and economic developments in the Greek economy. They use the VAR model for monthly data from 1988 to 2002, along with the Granger causality tests and the Johansen cointegration test. The results show that there is one cointegrated vector among the variables examined.

Caporale, Howells and Soliman (2004) use the VAR model to study the relationships between stock markets, investment and the economic growth for seven selected countries: Argentina, Chile, Greece, Korea, Malaysia, Philippines and Portugal, with quarterly data from 1977 to 1998 . The aim of the work was to find out whether earlier works not including the stock market had misleading results.

Ndako (2010) examines the relationship between equity markets, banks and economic growth with the VECM model on the quarterly time series from 1983 to 2007 for South Africa. His results indicate the presence of bi-directional causality and the importance of the role of financial sector in the South African economy.

Vazikidis and Adamopoulos (2009) use the VECM model to analyse the economy of France in the 1965-2007 period. They are primarily concerned with the question whether stock market development causes the economic growth or vice versa.

The paper by Megaravalli, Sampagnaro and Murray (2018) emphasizes the impact of macroeconomic variables on the stock market performance of a developing economy (India and China) and a developed economy (Japan). In the short run, there is no statistically significant relationship between macroeconomic variables and stock markets. Erdem and Arslan (2005) study effects of macroeconomic variables on Istanbul stock exchange indexes and Pal and Mittal (2011) deal with the impact of macroeconomic indicators on Indian capital markets. Hsing and Hsieh (2012) deal with impacts of macroeconomic variables on the stock market index in Poland. Ho, Odhiambo and Millan (2018) analyse the macroeconomic drivers of stock market development in the Philippines, Pilinkus (2010) evaluates macroeconomic indicators and their impact on stock market performance in the short and long run in the case of the Baltic countries. 
Marques et al. (2013) analyse this relationship in the case of Portugal. Cherif and Gazdar (2010) explore the institutional determinants for financial development in the countries of the Middle East and North African region.

Other articles dealing with V4 issues are, for example, the following. Růčková (2015) evaluates whether there is a functional dependency between the used financial sources and the reported rate of return on equity. The relationship between the real gross domestic product and the unemployment rate during the economic crisis in the countries of V4 is analysed in the paper Tvrdon (2016). The stock market integration of V4 and G7 countries is examined in the paper Baumöl (2014). The research showed that during the recent financial crisis, conditional correlations between the states of V4 have increased more significantly than after the entry of the states of V4 into the European Union. The paper by Nežinský and Baláž (2016) examines the predictive power of the confidence indicators for developments bin industrial output, producer prices and employment in the V4 countries. The Granger Causality tests are used for establishing potential causation between the confidence indicators and real economic data.

It is not always true that the stock market reflects the true state of the economy. While it is expected that the stock markets should fall in times of recession, they can grow as well. There are several reasons for it. The stock markets do not take into account the present, but the future. This was also demonstrated by the latest financial crisis, which appeared to happen a bit earlier in the stock markets in the USA than in the real economy. However, this does not apply to the V4 countries where there is a demonstrable correlation between the performance of the economy and the performance of stock markets. During the crisis in the V4 countries, both the performance of the economy and the performance of the stock markets declined. Stock markets can only differ from the real economy for a limited time. For example, Poland's economy (as the only country in the European Union) was not in recession during the crisis years. The growth of Slovakia's economy during the boom period is also worth attention. Moreover, the Slovak economy returned to a growth trend after the crisis. On the other hand, the economy of Hungary and the Czech Republic stagnated from 2008 to 2014. The current state of the GDP development shows that all economies have been able to restore the growth trend.

\section{Method}

\subsection{VAR/VECM Model}

The Vector Autoregressive Model (VAR) and the Vector Error Correction Model (VECM) make it possible to express and analyse a simultaneous relation between the variables. Arlt (1999) states that VAR analysis is based on the idea that all the variables used to analyse a selected dependency are random and simultaneously dependent. This means that the model structure contains only endogenous variables (except the deterministic components of the model), with their maximum delay time being the same (Juselius, 2006).

Time series can be analysed based on their short-term and long-term relations. If there is only a short-term relation between the time series, the VAR model is a sufficient tool for analysing this relation. If a long-term relation exists between selected time series, the VECM model can be used for the analysis. The VECM model simultaneously captures and expresses both short-term and long-term relations. The VECM model is based on a cointegration approach that models non-stationary time series the long-term relation of which is expressed through the error correction mechanism.

\subsection{Cointegration Analysis}

The cointegration analysis is based on the integrated processes that were first comprehensively addressed by Box and Jenkins. The cointegration analysis examines short-term dynamics and long-term relations between variables. Each system is subject to constant shocks, so it does not reach equilibrium in the short run (Johansen \& Juselius, 1990). Nevertheless, there may be a relation between the time series that can be considered as equilibrium in the long run. Arlt (2003) states, that Engle and Granger developed a simple cointegration test based on a residual stationarity test. The Engle and Granger approach can be described as a classic approach.

\subsection{Impulse-response Analysis}

Impulse-response analysis allows the of both the short-term and long-term relations between 
the analysed variables based on the derived model. Arlt (1999) states that the impulseresponse analysis is related to the question of what reaction in one time series will be caused by an impulse in another time series within a system that contains multiple time series. This is the study of the relation between two onedimensional time series in a multidimensional system.

\section{Development of V4 Countries}

The Visegrad Group is an alliance of four Central European countries: the Czech Republic, Slovakia, Poland and Hungary. Quarterly data for the period from 2005/Q1 to 2018/Q4 was used for the analysis. This period was selected because all of the V4 countries have been members of the European Union since 2004. The global fundamental analysis examines the impact of the economy and the market on the value of the share. It uses global macroeconomic indicators such as: interest rates, inflation, the gross domestic product, money supply, movement of international capital, movement of foreign exchange rates, political and economic shocks. This article discusses the relationship between the GDP, the stock trading volume and the index rate.

\subsection{Czech Republic}

This chapter uses data from analyzes of the Czech Statistical Office, the Ministry of Industry and Trade, the Ministry of Finance of the Czech Republic and the Prague Stock Exchange (2018).

\section{Economic Development}

The year 2004 is considered as the turning point when the transformed economy became a market economy. Previous reforms and the EU accession helped to develop exportoriented businesses. This trend lasted until 2008. The trend was halted only in the last quarter of 2008, when the global crisis broke out. The economy slowed significantly and fell into a deep recession. Growth in private consumption was negative in the third quarter of 2009, as households responded to rising unemployment and a decline in the wage growth. However, compared to other affected countries, the effects of the crisis were not so sky-high, as the very financial crisis causing the recession did not excessively affect the economy of the Czech Republic. The economy's performance improved and the recovery was stronger in 2014, when the Czech Republic's GDP growth of $2 \%$ equalized the decline of the previous two years to move the country out of recession. The economy has been growing since then.

\section{Stock Market}

The year 2004 was the most successful year of stock markets in the Czech Republic. The PX 50 index reached a sharp appreciation at the beginning of 2004 and continued its longterm growth trend with an overall year-on-year increase of $56.6 \%$. The year 2005 interrupted the grown of the PX 50 index, but there was again the overall appreciation in the course of the year. This development corresponded to the situation on the world financial markets responding to high prices of energy commodities, interest rate developments, etc. The index development in 2006 and 2007 was unstable and it was marked by strong fluctuations affected by the situation in the US stock markets in 2007, where the effects of the mortgage crisis began to appear. These consequences were fully reflected in 2008, causing the global financial collapse which led to the collapse of all stock indices on world stock exchanges. Compared to 2007, the PX 50 index was 53\% lower. There was a slight recovery in 2009 and the Czech stock market started to grow again. The PX index for the 2014-2015 showed a growing trend in 2016 the highest value fell PX index to 954 points in 2017 and increased to the highest value of 1,087 points (Wikipedia, 2019).

\subsection{Slovakia}

In the following, the development of the economy and stock market in Slovakia will be presented. The source of information is data from the OECD, the Slovak National Bank and the Bratislava Stock Exchange (2018).

\section{Economic Development}

Thanks to Slovakia's accession to the EU in 2004 , the real GDP grew by $4 \%$ YOY, exports increased and domestic demand was strong. The growth continued until 2009. The Slovak government tried to meet the Maastricht convergence criteria with a view to joining the Monetary Union and adopting the euro as a currency in 2009. The beginning of 2009 brought one of the highest real GDP declines among the OECD countries as a result of the financial crisis and the subsequent decline 
in world trade volumes on which the Slovak economy was dependent. The economy began to recover relatively quickly, and even surpassed its pre-crisis record by 2013. The GDP growth rate was increasing in the 2014-2018 period.

\section{Stock Market}

At the beginning of the 21st century the Slovak stock market was characterized by small volumes and insufficient liquidity. There was a rise in private share investment, but direct trades still prevailed over stock trades in 2004 . Stock trading volumes decreased by $60.6 \%$ compared to 2003 . The SAX index grew by $84 \%$ in this period. The index developed experienced a number of fluctuations in 2007. The value increased by $7.23 \%$. There were other large declines in stock trading volumes in 2012 and 2013 . The SAX index fell by $10.79 \%$ in 2012, but it broke down declining trends and slightly increased in 2013. The SAX index rose by $12.42 \%$ in 2014 . The SAX index had a growing trend, and the stock trading volume had a declining trend.

\subsection{Hungary}

The data in the following paragraph are based on the OECD, the Budapest Stock Exchange and the Hungarian Statistical Office.

\section{Economic Development}

At the turn of the millennium, the Hungarian economy was relatively strong and the country was one of the leading candidates for the EU membership. The GDP growth rates ranged between $4 \%$ and $5 \%$ in 2005 and 2006. The breakthrough occurred with the advent of the 2006 elections when the centre-left coalition was re-elected. Its government announced a financial consolidation plan. The government introduced new fiscal measures and structural reforms in the area of public spending, which exerted pressure on households, businesses and the public sector, and the pace of the GDP growth slowed significantly. Just before the outbreak of the crisis in September 2008, the Hungarian economy was able to meet its fiscal consolidation targets. Hungary was one of the countries heavily hit by the 2008 crisis, despite foreign aid. Thanks to a large amount of foreign investment, many households and companies got into debt, just like the country itself, the indebtedness of which amounted to $120 \%$ of the GDP. Year-on-year the GDP growth was negative $(-6.8 \%)$ in 2009 . There was an improvement and the year-on-year growth was $1.1 \%$ in 2010. This trend continued in 2011. After the crisis in 2012, Hungary returned to the growth trend of the year-on-year GDP growth. Improvements were seen in rising exports, increasing domestic demand and the domestic investment growth. The GDP growth rate was increasing in the 2014-2018 period.

\section{Stock Market}

The Budapest Stock Exchange was one of the most liquid in Central and Eastern Europe until 2000. The turn of the millennium brought problems to the stock exchange and the financial markets in Hungary. The BUX index grew by $19.5 \%$ in 2006 . The stock market continued in its positive development until 2008, when the Hungarian economy was hit by the financial crisis. This affected the value of the BUX index, which decreased by $53.3 \%$. The stock market had gradually begun to recover since 2009 . There was a slight improvement, but the stock market was still below its pre-crisis performance in 2012 and 2013. There were further declines and the Hungarian stock market moved away from the other stock markets of the region in 2014. The situation improved in the 2014-2018 period, and both the BUX and the stock trading volume showed a growing trend.

\subsection{Poland}

The data in the following paragraph is based on the OECD, the Warsaw Stock Exchange (2018) and the National Bank of Poland.

\section{Economic Development}

Together with other EU countries, Poland joined the EU in 2004. The EU accession was accompanied by a strong acceleration in the GDP growth. It declined to $3.2 \%$ in 2005 . However, the Polish economy recorded a 6\% GDP growth over the next two years. Since 2007, the Polish economy had been the most powerful of the OECD countries in the real GDP growth. The 2008 crisis hit Poland less than other European countries, thanks to the stability of its financial system. The GDP growth accelerated in 2010 and 2011, with a sharp downturn in 2012 and 2013. The GDP growth fell to a year-on-year increase of $1.4 \%$ in 2013 . This development is attributable to the collapse of public investment after 2012. The GDP growth rate was increasing in the 2014-2018 period. 


\section{Stock Market}

The period at the end of the millennium marked a downward trend for the WIG index, the official index of the Warsaw Stock Exchange. 2005 was marked by very low interest rates, which contributed to the development of the stock market. The stock market became the fastest growing segment of the capital market in Poland. The WIG index reached its peak, with a year-on-year increase of $33.7 \%$. This trend continued in 2006 and 2007. It made the fall in 2008 even worse, as the development was heavily influenced by the financial crisis. It caused a strong outflow of capital from the stock market, resulting in a sharp fall in stock prices. The stock market started to positively develop in 2010, when all indicators grew. There was another drop in prices in 2011 and the decline continued in 2012. 2013 was favourable for the Polish stock market, the WIG index rose by $26.2 \%$. The WIG index and the stock trading volume declined in the 2014-2016 period, but both the WIG index value and the stock trading volume have had a growing trend since 2016 .

\section{Relationships between Economic Development and Stock Markets}

Quarterly data for the period from 2005/Q1 to $2018 /$ Q4 was used for the calculations. All values were seasonally adjusted and were considered in logarithmic terms. The EViews software version 9 was used for the calculations.

Variables used in this research are: the GDP, the stock exchange index of the country, and the stock trading volume. The GDP is the variable representing the economic development of the countries studied. Data for the Czech Republic and Slovakia were obtained from the statistical offices, for Hungary and Poland from the Eurostat database. The PX, SAX, BUX and WIG20 stock indices are considered to be the crucial representatives of individual stock markets in this work. The stock market is also represented by the Amount Traded (AT) variable, which represents the volume of all traded shares for the given period. Time series were obtained from the Bloomberg database.

The modelling structure is similar for all the countries studied and consists of the following steps: testing the presence of unit roots, the VECM model estimation, impulse responses, Granger causality and block exogenity. The similar procedure is listed by Stoklasova (2018).

The variables (CR_GDP, CR_PX,CR_AT), (SR_GDP, SR_SAX, SR_AT), ( $\overline{H U}$ _GDP, HU

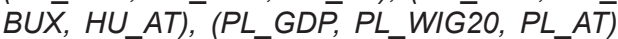
for the VAR model exhibit the properties of firstorder non-stationarity, i.e. I(1); therefore, the long-run cointegration relationships may exist between these variables. Using the Johansen's method, as shown in Johansen (1995), the existence of 1 cointegration relationship for the $\operatorname{VECM}(1)$ was confirmed. The result is the same for all states of V4.

\subsection{Czech Republic}

The preparatory phase of estimating the VAR model is testing the stationarity of variables included in the model or their first differences. The test results for all variables are provided in Tab. 1. The Dickey-Fuller test (ADF) was used to test the stationarity. The last column includes the result of testing: $\mathrm{N}=$ non-stationary $\left(H_{0}\right.$ not rejected), $\mathrm{S}=$ stationary $\left(H_{0}\right.$ rejected $)$.

Existence of one long-term bond can be specified by a cointegration equation:

$$
\begin{aligned}
& E Q \_C R=C R \_G D P_{t}-0.371 C R \_P X_{t}+ \\
& +0.465 C R \_A \bar{T}_{t}
\end{aligned}
$$

A cointegration vector expressing the equilibrium relationship between $C R \_G D P$, $C R \_P X$ and CR_AT is $(1.000 ;-0.371 ; 0.465)$. This means that a $1 \%$ increase in $C R P X$ will cause an increase in CR_GDP by $0.37 \overline{1} \%$, and

Tab. 1: Testing the unit root of the variables in levels and their first differences

\begin{tabular}{l|c|c|c|c|c|c|c|c|c}
\multicolumn{1}{c|}{ Variable } & $\mathbf{n} / \mathbf{c} / \mathbf{c + t}$ & T-stat & P-value & Result & Variable & $\mathbf{n} / \mathbf{c} / \mathbf{c + t}$ & T-stat & P-value & Result \\
\hline CR_GDP & $\mathrm{c}+\mathrm{t}$ & -1.06 & 0.925 & $\mathrm{~N}$ & $\mathrm{D}\left(\mathrm{CR} \_\mathrm{GDP}\right)$ & $\mathrm{c}+\mathrm{t}$ & -4.88 & 0.001 & $\mathrm{~S}$ \\
\hline CR_PX & $\mathrm{n}$ & -0.84 & 0.343 & $\mathrm{~N}$ & $\mathrm{D}(\mathrm{CR}$ _PX) & $\mathrm{c}+\mathrm{t}$ & -4.42 & 0.005 & $\mathrm{~S}$ \\
\hline CR_AT & $\mathrm{c}$ & 2.31 & 0.999 & $\mathrm{~N}$ & $\mathrm{D}(\mathrm{CR}$ _AT $)$ & $\mathrm{c}$ & -4.99 & 0.001 & $\mathrm{~S}$ \\
\hline
\end{tabular}




\section{Tab. 2: Estimates VECM (1)}

\begin{tabular}{c|c|c|c} 
Error correction & D(CR_GDP) & D(CR_PX) & D(CR_AT) \\
\hline \multirow{3}{*}{ CointEq1 } & -0.022991 & $-0.010164^{* * *}$ & $-0.041996^{* * *}$ \\
\cline { 2 - 4 } & $(0.04436)$ & $(0.00167)$ & $(0.00261)$ \\
\cline { 2 - 4 } & {$[-0.51826]$} & {$[-6.09233]$} & {$[-16.0863]$} \\
\hline \multirow{4}{*}{ D(CR_GDP(-1)) } & 0.062902 & $-0.014651^{* *}$ & $0.042799^{* * *}$ \\
\cline { 2 - 4 } & $(0.14932)$ & $(0.00562)$ & $(0.00879)$ \\
\hline \multirow{3}{*}{ D(CR_PX(-1)) } & {$[0.42126]$} & {$[-2.60897]$} & {$[4.87042]$} \\
\cline { 2 - 4 } & -0.084028 & $0.869893^{* * *}$ & $-0.493121^{* * *}$ \\
\cline { 2 - 4 } & $(0.88386)$ & $(0.03324)$ & $(0.05202)$ \\
\hline \multirow{3}{*}{ D(CR_AT(-1)) } & {$[-0.09507]$} & {$[26.1702]$} & {$[-9.48031]$} \\
\cline { 2 - 4 } & 0.207937 & -0.000283 & $1.047954^{* * *}$ \\
\cline { 2 - 4 } & $(0.14828)$ & $(0.00558)$ & $(0.00873)$ \\
\hline \multirow{3}{*}{ C } & {$[1.40235]$} & {$[-0.05069]$} & {$[120.093]$} \\
\cline { 2 - 4 } & 0.014800 & $-0.000582^{* * *}$ & $-0.003004^{* * *}$ \\
\cline { 2 - 4 } & $(0.00375)$ & $(0.00014)$ & $(0.00022)$ \\
\hline \multirow{2}{*}{ R-squared } & {$[3.94838]$} & {$[-4.12812]$} & {$[-13.6189]$} \\
\hline
\end{tabular}

Source: own

$1 \%$ increase in $C R \_A T$ will cause an decrease in CR_GDP by $0.465 \%$. This conclusion is in line with the assumption, because a positive relationship is assumed between the variables $C R \_G D P, C R \_P X$.

The results of the VECM(1) estimate did not demonstrate the statistical significance of the GDP correction component, as shown in Tab. 2. The model does not sufficiently explain the convergence to the long-term equilibrium defined by the cointegration equation. The residual component is not correlated, residual component heteroscedasticity and residual component non-normality were not demonstrated.

Impulse-responses trace the effects of structural shocks on the endogenous variables. Each response includes the effect of a specific shock on one of the variables of the system at impact $t$, the on $t+1$, and so on. The results are explained in graphics on the Fig. 1, which shows the impulse response functions. This article deals with the response of the GDP growth rate variable to shocks in the change in the PX index growth rate and the AT stock trading volume. There is no GDP response to the PX index shock or the AT shock.

This part deals with the testing of shortterm relationships (Granger causality). The hypothesis tested is that the series in question does not act in Granger's sense against an alternative hypothesis that denies the hypothesis tested. We consider the $5 \%$ significance level. When evaluating Granger causality, it is necessary to work with stationary time series. The results of the series 1 delay test are shown in Tab. 3.

Based on the significance, the zero hypothesis cannot be rejected: the PX growth rate neither affects the GDP growth rate nor the zero hypothesis: the stock trading volume does not affect the GDP growth rate. It was only demonstrated that the GDP growth rate is influenced by the PX index growth rate. The results of block exogenity (Tab. 4) show that together the variables representing the stock market affect the development of the economic growth. If we consider the PX and AT variables separately, the Granger test result is confirmed, i.e. the effect of PX development and the impact 


\section{Fig. 1: Response to Cholesky One S. D. Innovations}

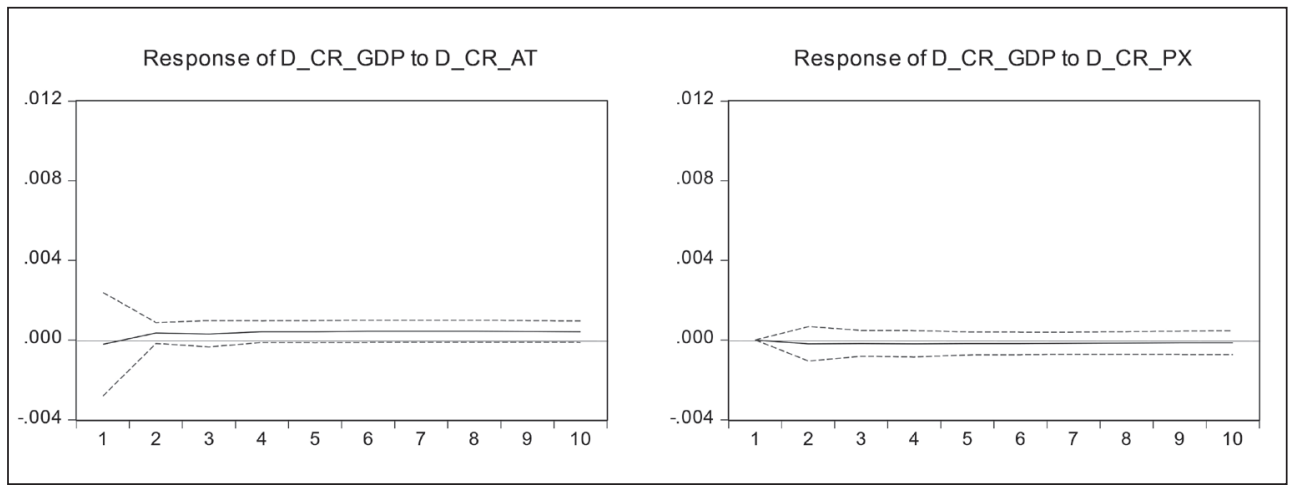

Source: own

\section{Tab. 3: Pairwise Granger causality tests (Lag 1)}

\begin{tabular}{l|c|c|c}
\multicolumn{1}{c|}{ Null hypothesis } & F-Statistic & P-value & $\begin{array}{c}\text { Results for } \\
\boldsymbol{\alpha}=\mathbf{0 . 0 5}\end{array}$ \\
\hline D(CR_PX) does not Granger Cause D(CR_GDP) & 1.24245 & 0.2703 & NO \\
D(CR_GDP) does not Granger Cause D(CR_PX) & 6.98069 & 0.0110 & YES \\
\hline D(CR_AT) does not Granger Cause D(CR_GDP) & 3.57698 & 0.0644 & NO \\
D(CR_GDP) does not Granger Cause D(CR_AT) & 0.58899 & 0.4464 & NO \\
\hline D(CR_AT) does not Granger Cause D(CR_PX) & 565.447 & $6 . E-29$ & YES \\
D(CR_PX) does not Granger Cause D(CR_AT) & $1,618.70$ & $9 . E-40$ & YES \\
\hline
\end{tabular}

\section{Tab. 4: Block Exogeneity Wald tests - dependent variable D(CR_GDP)}

\begin{tabular}{l|c|c|c}
\multicolumn{1}{c|}{ Excluded } & Chi-sq & df & Prob. \\
\hline D(CR_PX) & 0.009038 & 1 & 0.9243 \\
\hline D(CR_AT) & 1.966591 & 1 & 0.1608 \\
\hline All & 13.04737 & 2 & 0.0015 \\
\hline
\end{tabular}

of stock trading volume do not play a significant role in the development of the economic growth.

\subsection{Slovakia}

The variables (SR_GDP, SR_SAX, SR_AT) for the VAR model exhibit the properties of firstorder non-stationarity, i.e. I(1). It shows Tab. 5.

Existence of one long-term bond can be specified by a cointegration equation:

$$
E Q \_S R=S R \_G D P_{t}+1.216 S R \_S A X_{t}+
$$$$
+0.144 S R \_A \bar{T}_{t}
$$

A cointegration vector expressing the equilibrium relationship between $S R \_G D P$, $S R \_S A X$ and $S R \_A T$ is $(1.000 ; 1.216 ; 0.144)$. This means that a $1 \%$ increase in $S R \_S A X$ will cause a decrease in SR_GDP by $1.216 \%$, and a $1 \%$ increase in $\overline{S R}$ _AT will cause 
Tab. 5: Testing the unit root of the variables in levels and their first differences

\begin{tabular}{l|c|c|c|c|c|c|c|c|c} 
Variable & $\mathbf{n} / \mathbf{c} / \mathbf{c}+\mathbf{t}$ & T-stat & P-value & Result & Variable & $\mathbf{n} / \mathbf{c} / \mathbf{c}+\mathbf{t}$ & T-stat & P-value & Result \\
\hline SR_GDP & $\mathrm{c}+\mathrm{t}$ & -3.11 & 0.115 & $\mathrm{~N}$ & $\mathrm{D}\left(\mathrm{SR} \_\mathrm{GDP}\right)$ & $\mathrm{c}+\mathrm{t}$ & -5.041 & 0.001 & $\mathrm{~S}$ \\
\hline SR_SAX & $\mathrm{n}$ & -0.51 & 0.491 & $\mathrm{~N}$ & $\mathrm{D}\left(\mathrm{SR} \_\mathrm{SAX}\right)$ & $\mathrm{c}+\mathrm{t}$ & -3.656 & 0.035 & $\mathrm{~S}$ \\
\hline SR_AT & $\mathrm{c}+\mathrm{t}$ & -3.19 & 0.097 & $\mathrm{~N}$ & $\mathrm{D}\left(\mathrm{SR} \_A T\right)$ & $\mathrm{c}$ & -2.071 & 0.038 & $\mathrm{~S}$ \\
\hline
\end{tabular}

Source: own

an decrease in SR_GDP by $0.144 \%$. This conclusion is not in line with the assumption, because a positive relationship is assumed between the variables.

The results of the VECM(1) estimate demonstrated the statistical significance of the GDP correction component, as shown in Tab. 6. The model sufficiently explains the convergence to the long-term equilibrium defined by the cointegration equation. The CointEq1 value $(0.045)$ indicates that this time series is adjusted by $4.5 \%$ in the first quarter in the case of longterm instability of the dependent variable. In other words, complete elimination of instability would last approximately 22 months (1/0.045), it means almost 2 years. Regarding regression coefficients, it can be argued that the GDP is negatively related to the rise in the SAX stock index and the stock trading volume, with quarterly delays. Model assumptions are met.

Fig. 2 shows the impulse response functions. This article deals with the response of the GDP growth rate variable to shocks in the change in the SAX index growth rate and the AT stock trading volume. There is an immediate reaction in the case of $A T$, the effect of which persists for several periods. An immediate response is also triggered by the SAX index shock, but this shock is absorbed faster than in the case of AT.

\section{Tab. 6: Estimates VECM}

\begin{tabular}{|c|c|c|c|}
\hline Error correction & D(SR_GDP) & D(SR_SAX) & D(SR_AT) \\
\hline \multirow{3}{*}{ CointEq1 } & $0.044835^{* * *}$ & $-0.016073^{* * *}$ & $0.067268^{*}$ \\
\hline & $(0.01492)$ & $(0.00224)$ & $(0.03776)$ \\
\hline & [3.00534] & {$[-7.16767]$} & [1.78154] \\
\hline \multirow{3}{*}{ D(SR_GDP(-1)) } & 0.042170 & 0.027676 & 0.495568 \\
\hline & $(0.14409)$ & $(0.02166)$ & $(0.36470)$ \\
\hline & [0.29266] & [1.27784] & [1.35885] \\
\hline \multirow{3}{*}{ D(SR_SAX(-1)) } & $-0.197066^{* *}$ & $0.880563^{* * *}$ & $0.717930^{* * *}$ \\
\hline & $(0.09752)$ & $(0.01466)$ & $(0.24682)$ \\
\hline & {$[-2.02078]$} & [60.0723] & [2.90866] \\
\hline \multirow{3}{*}{$\mathrm{D}\left(\mathrm{SR} \_\mathrm{AT}(-1)\right)$} & $-0.095667^{* * *}$ & $-0.018677^{* * *}$ & $1.034930^{* * *}$ \\
\hline & $(0.02583)$ & $(0.00388)$ & $(0.06537)$ \\
\hline & {$[-3.70434]$} & {$[-4.81132]$} & [15.8330] \\
\hline \multirow{3}{*}{$\mathrm{C}$} & $0.006515^{* * *}$ & $-0.001197^{* * *}$ & $0.000730^{*}$ \\
\hline & $(0.00256)$ & $(0.00038)$ & $(0.00648)$ \\
\hline & [2.54436] & {$[-3.11092]$} & [0.11261] \\
\hline R-squared & 0.328278 & 0.995912 & 0.953314 \\
\hline
\end{tabular}




\section{Fig. 2: Response to Cholesky One S. D. Innovations}

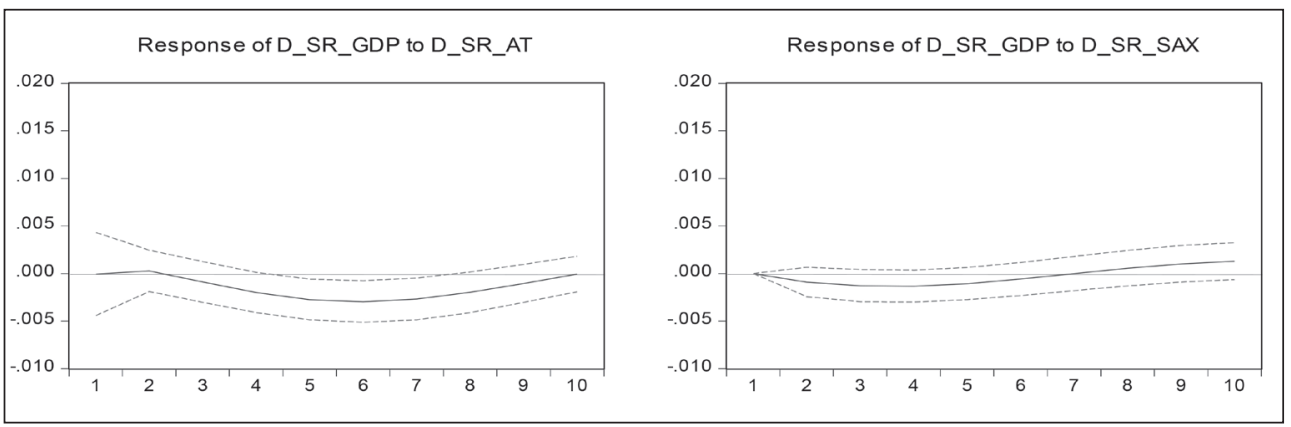

Source: own

\section{Tab. 7: $\quad$ Pairwise Granger causality tests (Lag 1)}

\begin{tabular}{l|c|c|c}
\multicolumn{1}{c|}{ Null hypothesis } & F-Statistic & P-value & $\begin{array}{c}\text { Results for } \\
\boldsymbol{\alpha}=\mathbf{0 . 0 5}\end{array}$ \\
\hline D(SR_SAX) does not Granger Cause D(SR_GDP) & 4.03415 & 0.0441 & YES \\
D(SR_GDP) does not Granger Cause D(SR_SAX) & 9.23387 & 0.0038 & YES \\
\hline D(SR_AT) does not Granger Cause D(SR_GDP) & 4.86803 & 0.0320 & YES \\
D(SR_GDP) does not Granger Cause D(SR_AT) & 0.47592 & 0.4935 & NO \\
\hline D(SR_AT) does not Granger Cause D(SR_SAX) & 113.680 & $2 . E-14$ & YES \\
D(SR_SAX) does not Granger Cause D(SR_AT) & 18.3562 & $8 . E-05$ & YES \\
\hline
\end{tabular}

Source: own

This part deals with the testing of short-term relationships (Granger causality). The results of the series 1 delay test are shown in Tab. 7 .

It was shown that the stock trading volume affects the GDP growth rate. Furthermore, it was shown that the change in the GDP growth rate causes a change in the SAX index growth rate. The results of block exogenity (Tab. 8) show that together the variables representing the stock market affect the development of the economic growth. We give the same result if we consider the SAX and AT variables separately. The effect of SAX development and the impact of stock trading volume play a significant role in the development of the economic growth.

\subsection{Hungary}

The variables (HU_GDP, HU_BUX, HU_AT) for the VAR model exhibit the properties of firstorder non-stationarity, i.e. I(1). It shows Tab. 9.

\section{Tab. 8: Block Exogeneity Wald tests - dependent variable D(SR_GDP)}

\begin{tabular}{l|c|c|c}
\multicolumn{1}{c|}{ Excluded } & Chi-sq & df & Prob. \\
\hline D(SR_SAX) & 4.083538 & 1 & 0.0433 \\
\hline $\mathrm{D}(\mathrm{SR}$ AT $)$ & 13.72210 & 1 & 0.0002 \\
\hline All & 14.41164 & 2 & 0.0007 \\
\hline
\end{tabular}


Tab. 9: Testing the unit root of the variables in levels and their first differences

\begin{tabular}{|c|c|c|c|c|c|c|c|c|c|}
\hline Variable & $n / c / c+t$ & T-stat & P-value & Result & Variable & $\mathrm{n} / \mathrm{c} / \mathrm{c}+\mathrm{t}$ & T-stat & P-value & Result \\
\hline HU_GDP & $\mathrm{c}+\mathrm{t}$ & -1.17 & 0.904 & $\mathrm{~N}$ & D(HU_GDP) & $c+t$ & -4.73 & 0.002 & S \\
\hline HU_BUX & $\mathrm{n}$ & 0.84 & 0.889 & $\mathrm{~N}$ & D(HU_BUX) & $c+t$ & -3.45 & 0.045 & $S$ \\
\hline HU_AT & $\mathrm{n}$ & 0.22 & 0.747 & $\mathrm{~N}$ & $\mathrm{D}\left(\mathrm{HU} \_\mathrm{AT}\right)$ & $\mathrm{n}$ & -2.12 & 0.034 & $S$ \\
\hline
\end{tabular}

Source: own

Existence of one long-term bond can be specified by a cointegration equation:

$$
\begin{aligned}
& E Q \_H U=H U \_G D P_{t}-0.171 H U_{-} B U X_{t}- \\
& -0.479 H U_{-} A T_{t}
\end{aligned}
$$

A cointegration vector expressing the equilibrium relationship between $H U_{-} G D P, H U_{-}$ $B U X$ and HU_AT is $(1.000 ;-0.17 \overline{1} ;-0.479)$. This means that a $1 \%$ increase in $H U \_B U X$ will cause an increase in $H U \_$GDP by $0.1 \overline{7} 1 \%$, and $1 \%$ increase in $H U$ AT will cause an increase in $H U \_G D P$ by $0 . \overline{4} 79 \%$. This conclusion is in line with the assumption, because a positive relationship is assumed between the variables.
The results of the $\operatorname{VECM}(1)$ estimate demonstrated the statistical significance of the GDP correction component, as shown in Tab. 10. The model sufficiently explains the convergence to the long-term equilibrium defined by the cointegration equation. The CointEq1 value $(0.043)$ indicates that this time series is adjusted by $4.3 \%$ in the first quarter in the case of long-term instability of the dependent variable. In other words, complete elimination of instability would lasted approximately 23 months (1/0.043), it means almost 2 year. Regarding regression coefficients, it can be argued that the GDP is positively related to the rise in the BUX stock index and negatively

\begin{tabular}{|c|c|c|c|}
\hline Error correction & D(HU_GDP) & D(HU_BUX) & D(HU_AT) \\
\hline \multirow{3}{*}{ CointEq1 } & $0.04301^{* *}$ & $0.050867^{* * *}$ & $0.054329^{* * *}$ \\
\hline & $(0.0186)$ & $(0.01030)$ & $(0.00678)$ \\
\hline & [2.31236] & [4.93676] & [8.01858] \\
\hline \multirow{3}{*}{ D(HU_GDP(-1)) } & $0.912854^{* * * *}$ & $-0.846498^{* * *}$ & -0.201845 \\
\hline & $(0.04165)$ & $(0.23026)$ & $(0.15141)$ \\
\hline & [21.9198] & {$[-3.67632]$} & {$[-1.33310]$} \\
\hline \multirow{3}{*}{ D(HU_BUX(-1)) } & $0.026600^{* * *}$ & $1.043974^{* * *}$ & -0.047021 \\
\hline & $(0.00785)$ & $(0.04343)$ & $(0.02856)$ \\
\hline & [3.38647] & [24.0382] & {$[-1.64651]$} \\
\hline \multirow{3}{*}{ D(HU_AT $(-1))$} & $0.020922^{* * *}$ & 0.017581 & $0.991229^{* * *}$ \\
\hline & $(0.00420)$ & $(0.02321)$ & $(0.01526)$ \\
\hline & {$[-4.98441]$} & {$[0.75755]$} & [64.9524] \\
\hline \multirow{3}{*}{ C } & $0.000475^{* *}$ & $0.004611^{* * *}$ & $0.001655^{* * *}$ \\
\hline & $(0.00024)$ & $(0.00131)$ & $(0.00086)$ \\
\hline & [2.00238] & [3.51268] & [1.91749] \\
\hline R-squared & 0.987846 & 0.971734 & 0.992469 \\
\hline
\end{tabular}

\section{Tab. 10: Estimates VECM}




\section{Fig. 3: Response to Cholesky One S. D. Innovations}

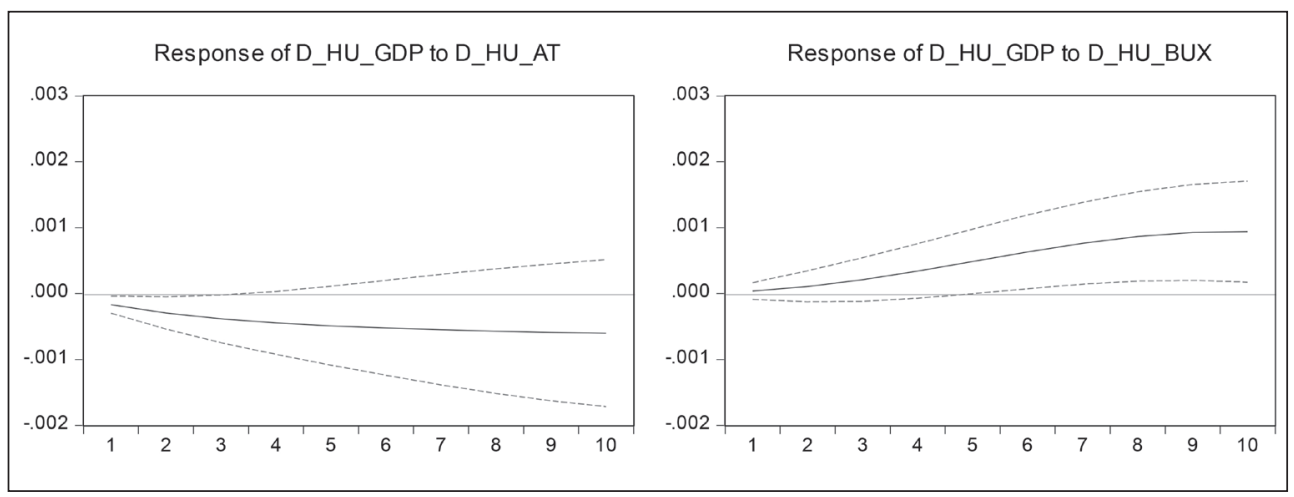

Source: own

\section{Tab. 11: Pairwise Granger causality test (Lag 1)}

\begin{tabular}{l|c|c|c}
\multicolumn{1}{c|}{ Null hypothesis } & F-Statistic & P-value & $\begin{array}{c}\text { Results for } \\
\boldsymbol{\alpha}=\mathbf{0 . 0 5}\end{array}$ \\
\hline D(HU_BUX) does not Granger Cause D(HU_GDP) & 5.67299 & 0.0062 & YES \\
D(HU_GDP) does not Granger Cause D(HU_BUX) & 39.3713 & $9 . \mathrm{E}-11$ & YES \\
\hline D(HU_AT) does not Granger Cause D(HU_GDP) & 17.5322 & $2 . \mathrm{E}-06$ & YES \\
D(HU_GDP) does not Granger Cause D(HU_AT) & 2.81491 & 0.0700 & NO \\
\hline D(HU_AT) does not Granger Cause D(HU_BUX) & 0.56836 & 0.5703 & NO \\
D(HU_BUX) does not Granger Cause D(HU_AT) & 3.99899 & 0.0249 & YES \\
\hline
\end{tabular}

related to the stock trading volume, with quarterly delays. Model assumptions are met.

Fig. 3 shows the impulse response functions. This article deals with the response of the GDP growth rate variable to shocks in the change in the BUX index growth rate and the AT stock trading volume. There is an immediate reaction in both the BUX and the AT variable, the effect of which persists for several periods.
This part deals with the testing of short-term relationships (Granger causality). The results of the series 1 delay test are shown in Tab. 11 .

It was shown that the stock trading volume affects the GDP growth rate. Furthermore, it was shown that the change in the BUX index growth rate causes a change in the GDP growth rate. And the change in the GDP growth rate causes a change in the BUX index growth

\section{Tab. 11: Pairwise Granger causality test (Lag 1)}

\begin{tabular}{l|c|c|c}
\multicolumn{1}{c|}{ Excluded } & Chi-sq & df & Prob. \\
\hline $\mathrm{D}(\mathrm{HU}$ BUUX $)$ & 11.46815 & 1 & 0.0007 \\
\hline $\mathrm{D}(\mathrm{HU}$ AT $)$ & 24.84439 & 1 & 0.0000 \\
\hline All & 30.46638 & 2 & 0.0000 \\
\hline
\end{tabular}


rate. The results of block exogenity (Tab. 12) show that together the variables representing the stock market affect the development of the economic growth. We give the same result if we consider the BUX and AT variables separately. The effect of BUX development and the impact of stock trading volume play a significant role in the development of the economic growth.

\subsection{Poland}

The variables ( $\left.P L_{-} G D P, P L \_W I G 20, P L \_A T\right)$ for the VAR model exhibit the properties of first-order non-stationarity, i.e. I(1). It is shown in Tab. 13.

Existence of one long-term bond can be specified by a cointegration equation:
$E Q \_P L=P L \_G D P_{t}-5.564 P L \_W I G 20_{t}+$

$+2.303 P L_{-} \bar{A} T_{t}$

A cointegration vector expressing the equilibrium relationship between $P L_{-} G D P, P L_{-}$ WIG20 and PL_AT is $(1.000 ;-5.564 ; 2.303)$. This means that a $1 \%$ increase in PL_WIG20 will cause an increase in $P L_{\text {_ GDP }}$ by $5.564 \%$, and $1 \%$ increase in PL_AT will cause an decrease in PL_GDP by $2.303 \%$. This conclusion is in line with the assumption, because a positive relationship is assumed between the variables PL_GDP, PL_WIG20.

The results of the VECM(1) estimate did not demonstrate the statistical significance of the

Tab. 13: Testing the unit root of the variables in levels and their first differences

\begin{tabular}{l|c|c|c|c|l|c|c|c|c}
\multicolumn{1}{c|}{ Variable } & $\mathbf{n} / \mathbf{c} / \mathbf{c}+\mathbf{t}$ & T-stat & $\mathbf{P}$-value & Result & Variable & $\mathbf{n} / \mathbf{c} \mathbf{c}+\mathbf{t}$ & T-stat & P-value & Result \\
\hline PL_GDP & $\mathrm{c}+\mathrm{t}$ & -3.13 & 0.111 & $\mathrm{~N}$ & $\mathrm{D}\left(\mathrm{PL} \_\mathrm{GDP}\right)$ & $\mathrm{c}+\mathrm{t}$ & -4.13 & 0.012 & $\mathrm{~S}$ \\
\hline PL_WIG20 & $\mathrm{n}$ & -0.39 & 0.537 & $\mathrm{~N}$ & $\mathrm{D}\left(\mathrm{PL} \_W I G 20\right.$ & $\mathrm{c}+\mathrm{t}$ & -3.97 & 0.016 & $\mathrm{~S}$ \\
\hline PL_AT & $\mathrm{c}+\mathrm{t}$ & -0.66 & 0.971 & $\mathrm{~N}$ & $\mathrm{D}\left(\mathrm{PL} \_\mathrm{AT}\right)$ & $\mathrm{c}+\mathrm{t}$ & -4.93 & 0.001 & $\mathrm{~S}$ \\
\hline
\end{tabular}

\section{Tab. 14: Estimates VECM}

\begin{tabular}{c|c|c|c} 
Error correction & D(PL_GDP) & D(PL_WIG20) & D(PL_AT) \\
\hline \multirow{4}{*}{ CointEq1 } & $-9.03 E-05$ & $0.010316^{* * *}$ & 0.000290 \\
\cline { 2 - 4 } & $(0.00027)$ & $(0.00130)$ & $(0.00201)$ \\
\cline { 2 - 4 } & {$[-0.34048]$} & {$[7.90625]$} & {$[0.14416]$} \\
\hline \multirow{4}{*}{ D(PL_GDP(-1)) } & $0.943906^{* * *}$ & -0.094725 & -0.203663 \\
\cline { 2 - 4 } & $(0.04163)$ & $(0.20489)$ & $(0.31603)$ \\
\hline \multirow{3}{*}{ D(PL_WIG20(-1)) } & {$[22.6732]$} & {$[-0.46232]$} & {$[-0.64445]$} \\
\cline { 2 - 4 } & $4.80 E-5$ & $0.949977^{* * *}$ & $-0.098242^{* *}$ \\
\cline { 2 - 4 } & $(0.00622)$ & $(0.03061)$ & $(0.04721)$ \\
\hline \multirow{3}{*}{ D(PL_AT(-1)) } & {$[0.00772]$} & {$[31.0362]$} & {$[-2.08089]$} \\
\cline { 2 - 4 } & -0.001689 & $0.042039^{*}$ & $0.932205^{* * *}$ \\
\cline { 2 - 4 } & $(0.00474)$ & $(0.02333)$ & $(0.03599)$ \\
\hline \multirow{3}{*}{ C } & {$[-0.35620]$} & {$[1.80188]$} & {$[25.9048]$} \\
\hline & 0.000471 & $9.18 E-05^{* * *}$ & -0.000244 \\
\cline { 2 - 4 } & $(0.00050)$ & $(0.00246)$ & $(0.00379)$ \\
\cline { 2 - 4 } & {$[0.94329]$} & {$[0.03737]$} & {$[-0.06425]$} \\
\hline R-squared & 0.962842 & 0.974624 & 0.978716 \\
\hline
\end{tabular}




\section{Fig. 4: Response to Cholesky One S. D. Innovations}

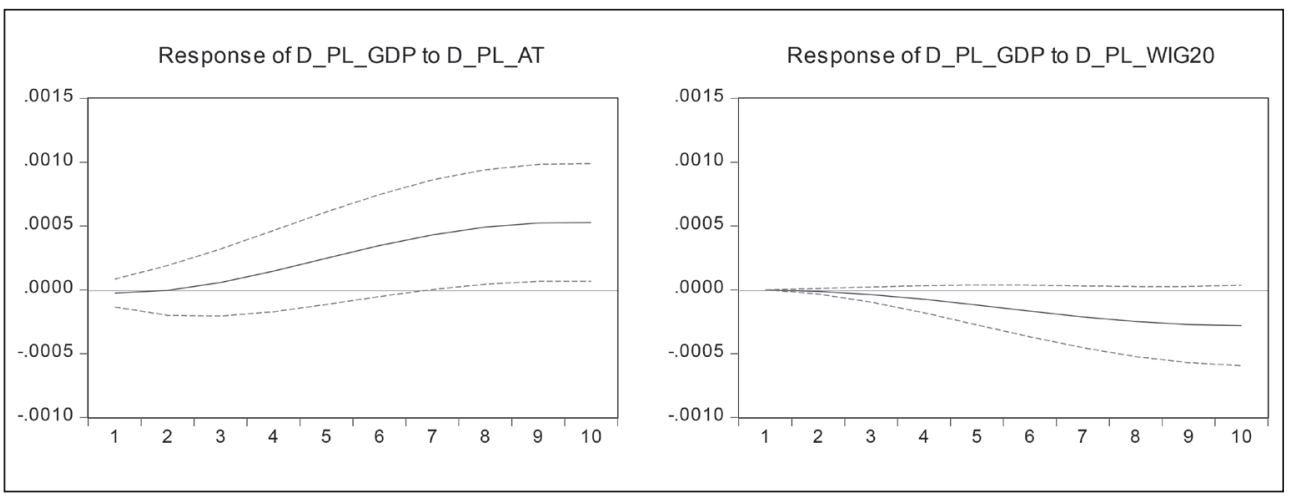

Source: own

\begin{tabular}{|c|c|c|c|}
\hline Null hypothesis & F-Statistic & P-value & $\begin{array}{c}\text { Results for } \\
\alpha=0.05\end{array}$ \\
\hline $\mathrm{D}(\mathrm{PL}$ WIG20) does not Granger Cause D(PL_GDP) & 0.79152 & 0.3779 & NO \\
\hline $\mathrm{D}\left(\mathrm{PL} \_\mathrm{GDP}\right)$ does not Granger Cause D(PL_WIG20) & 10.2153 & 0.0024 & YES \\
\hline $\mathrm{D}\left(\mathrm{PL} \_\mathrm{AT}\right)$ does not Granger Cause $\mathrm{D}(\mathrm{PL}$ G GP) & 36.1890 & 2.E-07 & YES \\
\hline $\mathrm{D}\left(\mathrm{PL} \_\mathrm{GDP}\right)$ does not Granger Cause $\mathrm{D}\left(\mathrm{PL} \_\mathrm{AT}\right)$ & 80.3058 & 6.E-12 & YES \\
\hline $\mathrm{D}\left(\mathrm{PL} \_A T\right)$ does not Granger Cause $\mathrm{D}(\mathrm{PL}$ _WIG20) & 6.73700 & 0.0124 & YES \\
\hline $\mathrm{D}(\mathrm{PL}$ WIG20) does not Granger Cause D(PL_AT) & 10.4137 & 0.0022 & YES \\
\hline
\end{tabular}

Source: own

GDP correction component, as shown in Tab.14. The model does not sufficiently explain the convergence to the long-term equilibrium defined by the cointegration equation. Model assumptions are met.

There is an immediate reaction in the GDP growth rate in the case of both the WIG20 and the AT variables.
This part deals with the testing of short-term relationships (Granger causality). The results of the series 1 delay test are shown in Tab. 15.

It was shown that the stock trading volume affects the GDP growth rate. Furthermore, it was shown that the change in the GDP growth rate causes a change in the WIG20 growth rate and also a change in the AT growth rate. The results

\section{Tab. 16: Block Exogeneity Wald tests - dependent variable D(PL_GDP)}

\begin{tabular}{l|c|c|c}
\multicolumn{1}{c|}{ Excluded } & Chi-sq & df & Prob. \\
\hline $\mathrm{D}(\mathrm{PL}$-WIG20) & $5.96 \mathrm{E}-05$ & 1 & 0.9938 \\
\hline $\mathrm{D}(\mathrm{PL}$ AT $)$ & 0.126881 & 1 & 0.7217 \\
\hline All & 0.182432 & 2 & 0.9128 \\
\hline
\end{tabular}


of block exogenity (Tab. 16) show that together the variables representing the stock market do not affect the development of the economic growth. The effect of WIG20 development and the impact of stock trading volume do not play a significant role in the development of the economic growth if we consider the variables separately.

\section{Conclusions}

It is not always true that the stock market accurately reflects the true state of the economy. While it is expected that the stock markets should fall in times of recession, uncertainty or political upheaval, they can fall, as well as grow. How is it possible? There are several reasons for it. The stock markets do not take into account the present, but the future. Therefore, they may be through an ongoing economic downturn, and now they are expecting a recovery. This was also demonstrated by the latest financial crisis, which appeared to happen a bit earlier in the stock markets than in the real economy.

The correlation between the economy performance and the stock market performance is evident. The theoretical model of the economy predicts that income from shares should reflect the economic growth but, in fact, these two figures are very different. During the 2008 financial crisis, stock markets across the globe fell by 40 to $60 \%$, but no economy experienced such a sharp drop, as reported by Wise-Owl. com (2018).

The long-term relationship between the development of stock markets and the economic growth was confirmed in Slovakia and Hungary. For Slovakia, this series will be adjusted by $4.5 \%$ in the first quarter in the case of the long-term GDP instability. In other words, complete elimination of instability would last approximately for almost 2 years. Cointegration equation (2) shows that the GDP is negatively affected in the long run by the growth rate of the SAX stock index and the stock trading volume. For Hungary, this series will be adjusted by $4.3 \%$ in the first quarter in the case of the long-term GDP instability. In other words, complete elimination of instability would last approximately for almost 2 years. Cointegration equation (3) shows that the GDP is positively affected in the long run by the growth rate of the SAX stock index and the stock trading volume.

It was confirmed that the income from shares reflects the economic growth in all V4 countries, coinciding with the theoretical model. The changes in the GDP growth rate affect the changes in the growth rate of stock indices in the Granger sense. Conversely, the hypothesis that the changes in the stock trading volume do not affect the changes in the GDP growth rate in the Granger sense was not rejected only for the Czech Republic. Therefore, it is true for the other countries that the economic growth reflects the income from shares in the shortterm.

Typically, stock market and economic performance will often be aligned. Thus, when the stock market is performing well it is usually a function of a growing economy. When GDP is growing, individual businesses are producing more and usually expanding. Expanding business activity usually increases valuations and leads to stock market gains. Historically, the steep market also declines preceded during the financial crisis 2007-2009. Some experts believe markets predict what the economy will be doing in about six months.

The stock market contributes to the nation's economy. Stocks affect the economy in three critical ways. The first way is that the stocks allow individual investors to own part of a successful company. Without stocks, only large investors could profit. The second way is that the stocks provide the capital for companies to gain a competitive advantage. The last way is that falling stock prices mean investors have lost confidence in the company's ability to increase its profit margins.

Naturally, there is a positive relationship between economic growth and the stock growth - as demonstrated by the fact that there is no prosperous economy without a capital market anywhere in the world. However, it is not possible to rely on any simple rule or elegant mathematical model that would clarify the relationship between the income from shares and the economic growth.

New macroeconomic data confirmed that the dynamics of the world economy is further slowing slightly. However, stock market developments were above expectations. And what were the financial markets in 2019? Government bonds of all V4 countries continued to grow.

The article dealt with the effects of the stock market on the economy in individual countries. Why is the mutual dependence of the GDP and income from shares different in 
the V4 countries? The reason is the statistical behaviour of stock indices and the economic growth. The long-term growth trend, which adds to the effects of short-term fluctuations, plays a major role in both cases. However, short-term fluctuations are not very important either for the development of the economy or for long-term income from the stock market.

The global financial crisis may be a factor in this investigation because during the economic crisis (2007-2008), the external economic equilibrium was not favorable. Suggestions for further research: comparison of the relationship between the development of stock markets and the economic growth in V4 before and after the financial crisis. Further research can be extended to these countries: the United States of America, Japan and the European Union.

Acknowledgement: This paper was supported by the project no. SGS/19/2019, Application of Customer Relationship Management Systems in Small and Medium-sized Enterprises accepted in 2019.

\section{References}

Arestis, P., Demetriades, P. O., \& Luintel, K. B. (2001). Financial Development and Economic Growth: The Role of Stock Markets. Journal of Money, Credit and Banking, 33(1), 16-41. https://doi.org/10.2307/2673870

Arlt, J. (1999). Moderní metody modelování ekonomických časových raad. Prague: Grada Publishing.

Arlt, J. (2003). Statistikům a ekonometrům byla udělana Nobelova cena za ekonomii za rok 2003. Informační bulletin České statistické společnosti, 3(14).

Baumöhl, E. (2014). Determinanty integrácie akciových trhov krajín V4. Politická ekonomie, 62(3), 347-365. https://doi. org/10.18267/j.polek.955

Bekaert G., \& Harvey, C. R. (1998). Capital Markets: An Engine for Economic Growth. The Brown Journal of World Affairs, 5(1), 33-53.

Bratislava Stock Exchange. (2018). Retrieved March 30, 2019, from http://www. bsse.sk/default.aspx

Budapest Stock Exchange. (2014). An Eventful Year for Stock Exchanges - the Summary of Last Year at the Budapest Stock Exchange. Retrieved March 30, 2019, from https://bse.hu/data/cms188918/BSE_ summary_2014.pdf
Caporale, G. M., Howells, P. G., \& Soliman, A. M. (2004). Stock Market Development and Economic Growth: The Causal Linkage. Journal of Economic Development, 29(1), 33-50. Retrieved December 10, 2018, from http://www. jed.or.kr/full-text/29-1/02_J665_.PDF

Cherif, M., \& Gazdar, K. (2010). Macroeconomic and Institutional Determinants of Stock Market Development in MENA Region: New Results from a Panel Data Analysis. International Journal of Banking and Finance, 7(1), 139-159. https://doi.org/10.32890/ ijbf2010.7.1.8403

Czech Statistical Office of the Czech Republic. (2018). Retrieved March 20, 2019, from http://www.czso.cz/

Dritsaki, Ch., \& Dritsaki-Bargiota, M. (2005). The Causal Relationship between Stock, Credit Market and Economic Development: An Empirical Evidence for Greece. Economic Change and Restructuring, 38(1), 113-127. https://doi.org/10.1007/s10644-005-4525-3

Erdem, C., Arslan, C. K., \& Sema Erdem, M. (2005). Effects of Macroeconomic Variables on Istanbul Stock Exchange Indexes. Applied Financial Economics, 15(14), 987-994. https://doi.org/10.1080/09603100500120365

Ho, S.-Y., Odhiambo, N. M., \& McMillan, D. (2018). Analysing the Macroeconomic Drivers of Stock Market Development in the Philippines. Cogent Economics \& Finance, 6(1), 1-18. https:// doi.org/10.1080/23322039.2018.1451265

Hsing, Y., \& Hsieh, W.-J. (2012). Impacts of Macroeconomic Variables on the Stock Market Index in Poland: New Evidence. Journal of Business Economics and Management, 13(2), 334-343. https://doi.org/10.3846/16111699.20 11.620133

Hungarian Central Statistical Office. (2018). Retrieved January 30, 2019, from http://www. ksh.hu/

Johansen, S., \& Juselius, K. (1990). Maximum Likelihood Estimation and Inference on Cointegration - With Applications to the Demand for Money. Oxford Bulletin of Economics and Statistics, 52(2), 169-210. https://doi.org/10.1111/j.1468-0084.1990. mp52002003.x

Johansen, S. (1995). Likelihood-based Inference in Cointegrated Vector Autoregressive Models. Oxford: Oxford University Press.

Juselius, K. (2006). The Cointegrated VAR Model: Methodology and Applications. Oxford: Oxford University Press. 
Marques, L. M., Fuinhas, J. A., \& Marques, A. C. (2013). Does the Stock Market Cause Economic Growth? Portuguese Evidence of Economic Regime Change. Economic Modelling, 32, 316-324. https://doi. org/10.1016/j.econmod.2013.02.015

Megaravalli, A. V., Sampagnaro, G., \& Murray, L. (2018). Macroeconomic Indicators and their Impact on Stock Markets in ASIAN 3: A Pooled Mean Group Approach. Cogent Economics \& Finance, 6(1), 1-14. https://doi.or $\mathrm{g} / 10.1080 / 23322039.2018 .1432450$

Ministry of Industry and Trade of the Czech Republic. (2018). Retrieved March 30, 2019, from http://www.mfcr.cz/

Ministry of Finance of the Czech Republic. (2018). Retrieved March 30, 2019, from http://www.mpo.cz/

National Bank of Slovakia. (2018). Retrieved March 30, 2019, from http://www.nbs. sk/sk/titulna-stranka

National Bank of Poland. (2018). Retrieved March 30, 2019, from http://www.nbp.pl/

Ndako, U. B. (2010). Stock Markets, Banks and Economic Growth: Time Series Evidence from South Africa. The African Finance Journal, 12(2), 72-92.

Nežinský, E., \& Baláž, V. (2016). Are the Confidence Indicators Meaningful for Forecasting Real Economy? Testing Power of Confidence Indicators for Industry Output, Prices and Employment in the Visegrád Group Countries. Ekonomický časopis, 64(10), 923-936.

OECD. (2017). Economic Surveys: Hungary 2017. Retrieved January 10, 2019, from https:// doi.org/10.1787/19990529

OECD. (2017). Economic Surveys: Slovak Republic 2017. Retrieved January 10, 2019, from https://doi.org/10.1787/eco_surveys-svk-2017

OECD. (2017). Economic Surveys: Poland 2017. Retrieved January 10, 2019, from http://dx.doi.org/10.1787/eco_surveys-pol-2017-en

Olweny, T. O., \& Kimani, D. (2011). Stock Market Performance and Economic Growth: Empirical Evidence from Kenya Using Causality Test Approach. Advances in Management and Applied Economics, 1(3), 153-196.

Pal, K., \& Mittal, R. (2011). Impact of Macroeconomic Indicators on Indian Capital Markets.
The Journal of Risk Finance, 12(2), 84-97. https://doi.org/10.1108/15265941111112811

Pilinkus, D. (2010). Macroeconomic Indicators and their Impact on Stock Market Performance in the Short and Long Run: The Case of the Baltic States. Technological and Economic Development of Economy, 16(2), 291-304. https://doi.org/10.3846/tede.2010.19

Prague Stock Exchange. (2018). Retrieved January 10, 2019, from http://www.pse.cz/

Růčková, P. (2015). Dependency of Return on Equity and Use of Finance Sources in Building Companies in V4 Countries. E\&M Economics and Management, 18(3), 73-83. https://doi.org/10.15240/tul/001/2015-3-007

Stoklasová, R. (2018). Default Rate in the Czech Republic Depending on Selected Macroeconomic Indicators. E\&M Economics and Management, 21(2), 69-82. https://doi. org/10.15240/tul/001/2018-2-005

Tvrdoň, M. (2016). Decomposition of Unemployment: The Case of The Visegrad Group Countries. E\&M Economics and Management, 19(1), 4-16. https://doi.org/10.15240/tul/001/2016$1-001$

Vazakidis, A., \& Adamopoulos, A. (2009). Stock Market Development and Economic Growth. American Journal of Applied Sciences, 6(11), 1932-1940. https://doi.org/10.3844/ ajassp.2009.1932.1940

Visegrad Declaration. (1991). The Visegrad Group: the Czech Republic, Hungary, Poland and Slovakia. Retrieved March 30, 2019, from http://www.visegradgroup.eu/ main. php? folderID $=940$ \&article ID $=3940$ \& ctag=articlelist\&iid $=1$

Wanzala, R. W., Muturi, W., \& Olweny, T. (2017). The Nexus between Market Tightness and Economic Growth - A Case of Kenya. Journal of Finance and Economics, 5(6), 259268. https://doi.org/10.12691/jfe-5-6-2

Warsaw Stock Exchange. (2018). Retrieved March 10, 2019, from https://www.gpw.pl/root_en

Wikipedia. (2019). Retrieved January 10, 2019, from https://en.wikipedia.org/wiki/PX_Index

Wise-Owl.com. (2018). Retrieved March 30, 2019, from https://www.wise-owl.com/ investment-education/is-there-a-correlationbetween-gdp-growth-and-stock-market-return 